\title{
Novel nematode species in living stromatolites in the Andean Puna
}

\section{Romina Elisa D’Almeida1', Marcia Elizabeth García², María Florencia Pérez², María Eugenia Farías ${ }^{2}$, Julián Rafael Dib ${ }^{2,3^{*}}$}

\author{
${ }^{1}$ Instituto Superior de Investigaciones Biológicas - Consejo Nacional de Investigaciones Científi- \\ cas y Técnicas.T4000 Tucumán,.Argentina.E-mail: rominadalmeida@gmail.com \\ ${ }^{2}$ Planta Piloto de Procesos Industriales Microbiológicos - Consejo Nacional de Investigaciones \\ Científicas y Técnicas.T4000 Tucumán,Argentina. E-mail: marciaeg.meg@gmail.com ; \\ mfp_1206@hotmail.com; mefarias@proimi.org.ar \\ ${ }^{3}$ Instituto de Microbiología, Facultad de Bioquímica, Química y Farmacia, Universidad Nacional \\ de Tucumán.T4000 Tucumán, Argentina.E-mail: jdib@proimi.org.ar
}

\begin{abstract}
The recently discovered "living" stromatolites in the Argentinean Puna are considered one of the most extreme stromatolites found so far. A rich biodiversity of bacteria and archaea were previously reported in such stromatolites. As nematodes are the most numerous multicellular animals on Earth, the aim of this work was to investigate their presence in the stromatolites from Socompa lake at 3570 meters above sea level (masl). Nematodes were extracted and identified as belonging to the Monhysteridae family, with 91-92\% homology to Diplolaimella dievengatensis. The phylogenetic analysis suggested they are novel species and probably belong to a new genus. This study represents the first report related to the presence of novel nematodes in such peculiar stromatolites. Knowing their functions and genetic features involved in the adaptation to these harsh conditions could help to elucidate important aspects about the ecological impact of these organisms in hostile environments.

How to cite this article: D’Almeida R.E., García M.E., Pérez M.F., Farías M.E., Dib J.R. 2019. Novel nematode species in living stromatolites in the Andean Puna // Invert. Zool. Vol.16. No.3. P.211-218, video. doi: 10.15298/invertzool.16.3.01
\end{abstract}

KEY WORDS: nematodes, stromatolites, extreme environment, Puna, Monhysteridae.

\section{Новый вид нематод из пресноводных строматолитов Андского плоскогорья}

\author{
Ромина Элиза Д'Алмейро', Марсия Элизабет Гарсия², \\ Мария Флоренция Перез², Мария Евгения Фариас², \\ Джулиан Рафраэль Диб $2,3^{*}$
}

\footnotetext{
${ }^{I}$ Instituto Superior de Investigaciones Biológicas - Consejo Nacional de Investigaciones Cientificas y Técnicas.T4000 Tucumán, Argentina.E-mail: rominadalmeida@gmail.com

${ }^{2}$ Planta Piloto de Procesos Industriales Microbiológicos - Consejo Nacional de Investigaciones Científicas y Técnicas. T4000 Tucumán, Argentina. E-mail: marciaeg.meg@gmail.com; mfp_1206@hotmail.com; mefarias@proimi.org.ar

${ }^{3}$ Instituto de Microbiología, Facultad de Bioquímica, Química y Farmacia, Universidad Nacional de Tucumán.T4000 Tucumán, Argentina.E-mail: jdib@proimi.org.ar
} 
РЕЗЮМЕ: Недавно обнаруженные живые строматолиты Андского плоскогорья считаются самыми необычными из всех известных ранее. Богатство разнообразия бактерий и архей было ранее отмечено для строматолитов. Поскольку нематоды самые многочисленные многоклеточные на планете Земля, то задачей работы было обнаружение нематод в строматолитах озера Сокомпа, расположенного на 3570 метров над уровнем моря. В ходе работы нематоды были обнаружены и определены как принадлежащие семейству Monhysteridae и с вероятностью 91-92\% отнесены к виду Diplolaimella dievengatensis. В то же время филогенетический анализ показал, что обнаруженный вид представляет собой новый для науки вид, принадлежащий неописанному ранее роду нематод. Настоящая работа представляет собой краткое информационное сообщение о первой находке нематод в необычных пресноводных строматолитах. Новые знания о функциональных и генетических особенностях, приведших к адаптации в необычных условиях среды, позволят понять экологическую роль нематод в сообществах пресноводных строматолитов.

Как цитировать эту статью: D’Almeida R.E., García M.E., Pérez M.F., Farías M.E., Dib J.R. 2019. Novel nematode species in living stromatolites in the Andean Puna// Invert.Zool. Vol.16. No.3. P.211-218, video . doi: 10.15298/invertzool.16.3.01

КЛЮЧЕВЫЕ СЛОВА: нематоды, строматолиты, экстремальные условия среды, Андское высокогорное плато, Monhysteridae

\section{Introduction}

Socompa lake is located in the high-altitude Andean plateau region known as the Puna (3570 meters above sea level-masl-), at the base of the volcano Socompa, in the northwest of Argentina. Along the southern shore of this volcanic lake, modern stromatolites have been identified (Farías et al., 2013). Stromatolites are layered forms of microbialites, which are organo-sedimentary deposits accreted by sediment trapping, binding and in situ precipitation due to the growth and metabolic activities of microorganisms (Walter, 1976). These stromatolites have developed under extreme environmental conditions such as high exposition to UV radiation, low rates of precipitation and high temperature fluctuations between day and night (Houston et al., 2003; Luccini et al., 2006). The Socompa lake water is alkaline, hypersaline, rich in inorganic nutrients and relatively warm $\left(20-24^{\circ} \mathrm{C}\right)$, due to the hydrothermal input from the volcanic system (Zappettini et al., 2001). The microorganisms present in the stromatolites might have special adaptations to survive under the lake conditions, representing genomic and proteomic reserves that are interesting to study. Al- though prokaryotic communities were already reported in the Socompa stromatolites, eukaryotic organisms were not entirely identified (Farías et al., 2013; Gorriti et al., 2014).

Nematodes are the most numerous multicellular animals on Earth, referred as typical representatives of Metazoa. There are more than 15,000 described species in the Phylum Nematoda (Barker, 1998), found in soil, freshwater, and marine environments as parasites of insects, plants or animals; or free-living forms, which are abundant, and include nematodes that feed on bacteria, fungi, and other nematodes.

According to our knowledge, there is no report on the description of isolated nematodes in the conditions that prevail over the stromatolites of the Andean Socompa Lake. Therefore, the discovering of nematodes at these conditions would bring new insights about the role of nematodes in such environments and broaden the knowledge about the microbial ecology associated with these living stromatolites.

In this study, we isolated and described for the first time the presence of new species of nematodes in the stromatolites formed at the shore of the high-altitude volcanic lake Socompa, in the Andean Puna. 


\section{Materials and Methods}

\section{Sampling and nematode isolation}

Stromatolite and water samples were collected in sterile plastic bags and flasks, respectively, and stored at $4{ }^{\circ} \mathrm{C}$ until been processed in the laboratory. Permission for sample collection was granted by the Ministerio de Ambiente y Desarrollo Sustentable, Salta, Argentina (number 000388; 17-09-2010).

Nematodes were separated from the stromatolites using the Agar culture plate method (Barrière et al., 2006). This method consists of placing the sample around a bacterial lawn and the bacterial-feeding nematodes crawl out the sample of the attracting food. Two different agar plates were prepared to isolate nematodes, one with WJK agar medium, specific for halophilic bacteria (Maldonado, 2014); and other with Nematode Growth Medium (NGM), specific for the model nematode Caenorhabditis elegans (Brenner, 1974). In the middle of each plate a mix of a fresh culture of two cyanobacteria (Microcoleus sp. and Anabaena sp.), previously isolated from the stromatolite, was inoculated and incubated at $25^{\circ} \mathrm{C}$ during two-three days, as attractant food.

The stromatolite samples were daily rehydrated with autoclaved and filtered Socompawater to simulate natural conditions. The dishes were placed in the dark at $15^{\circ} \mathrm{C}$ under high humidity conditions, and every hour, during the first five hours, observations under a Nikon Eclipse 80i light microscope were made to pick the worms that crawled out the samples. The observations were repeated every day until no more nematodes were obtained.

Baermann and centrifugal flotation methods (Barrière et al., 2006) were also tried to extract the nematodes, using both fresh stromatolites samples and lake water.

\section{Culturing attempt}

Attempts were made to culture the nematodes using NGM and Vlasblom medium. Vlasblom medium is used to grow and maintain certain species of saline nematodes (Jacobs et al., 1990). In the preparation of both media, filtered water from the Socompa Lake was used. As food sources, the mix of cyanobacteria ( $M i$ crocoleus sp. and Anabaena sp.) or Escherichia coli OP50 (Brenner, 1974), were used to inoculate the plates. Nematodes were extracted from the stromatolite samples as mentioned above and transferred to bacterial lawns on NGM agar or Vlasblom's medium plates. The transferred nematodes were kept at 15 and $25^{\circ} \mathrm{C}$ and were examined daily under a dissecting microscope.

\section{Morphological and molecular ana-} lysis

Nematode images were obtained using a Nikon Eclipse 80i light microscope. Videos of specimens were taken with a Leica ICC50 camera mounted on a LEICA DM500 light microscope. Nematode measurements were taken using the image analysis software Leica Application Suite (LAS EZ v.3.0.0).

Morphological identification was performed taking into account basic morphological characteristics that were compared with the NeMys database (Accessed at http://nemys.ugent.be on 2018-11-14).

For the molecular analysis of the conserved 18S rDNA (small subunit: SSU) gene, DNA extraction were done using DNeasy ${ }^{\circledR}$ Tissue and Blood kit (QIAGEN) according to the manufacturer's instructions. DNA concentrations were estimated by measuring the absorbance at $260 \mathrm{~nm}$.

The 18 S region was amplified by PCR using the following primer pairs, SSU18A (AAAGATTAAGCCATGCATG) and SSU26R (CATTCTTGGCAAATGCTTTCG) (Blaxter, De Ley, Garey Liu, 1998); and RHAB1350F (5'-TACAATGGAAGGCAGCAGGC-3') and RHAB186R (5'-CCTCTGACTTTCGTTCTTGATTAA-3') (Haber et al., 2005). $50 \mathrm{nM}$ of DNA template was used for PCR amplification in a $50 \mu \mathrm{l}$ reaction mixture in the presence of Taq Polymerase (Invitrogen, Carlsbad, CA). PCR was performed in an automated thermal cycler (Ivema T18, Argentina) with an initial $94{ }^{\circ} \mathrm{C}$ denaturation for $3 \mathrm{~min}$, followed by 30 cycles of $94{ }^{\circ} \mathrm{C}$ for $45 \mathrm{sec}, 56{ }^{\circ} \mathrm{C}$ for $30 \mathrm{sec}$, $72{ }^{\circ} \mathrm{C}$ for $1.5 \mathrm{~min}$ and a final extension at $72{ }^{\circ} \mathrm{C}$ 
for $10 \mathrm{~min}$. After agarose gel electrophoresis of PCR products, they were stained with SYBR $\operatorname{Red}{ }^{\circledR}$ and visualized with UV trans-illumination. Sequence Similarity Searching using BLAST was used to identify related sequences. (http://www.ncbi. nlm.nih.gov/BLAST/).

For the phylogenetic analysis, DNA sequences were edited and assembled using Clone Manager 9 (http://www.scied.com). SINA Aligner (v1.2.11) was used to align the DNA (Pruesse $e t$ $a l ., 2012)$ and the resulting alignment was then manually improved. Maximum likelihood analysis (500 bootstrap replicates for estimation of branch support) was carried out with MEGA X (Kumar et al., 2018) using the Tamura 3=parameter substitution model, with gamma parameters, and a transition/tranversion ratio of 1.334 .

\section{Results}

\section{Nematode isolation}

Different extraction methods reported in bibliography were used, obtaining satisfactory results only with the agar plate method. Several nematodes with high mobility could be observed on the agar surface (Supporting information, Video S1).

\section{Culturing attempts}

Culturing attempts for further studies on the nematodes from Socompa stromatolites were performed. However, the individuals could not survive under the tested in vitro conditions for more than one month. The isolated nematodes showed no feeding behavior neither on the mix of Socompa cyanobacteria, nor on the E. coli OP50 strain, and died out within one month of inoculation.

\section{Morphological and molecular ana- lysis}

From the morphological identification following the NeMys database, nematodes belonging to the Monhysteridae family were identified, with characteristics similar to the genus Diplolaimella. Isolates presented a slender body, with $1 \mathrm{~mm}$ length and almost equal diameter between nerve ring and anus, tail long and filiform. One pair of ocelli was observed, with a dorso-lateral position with respect to pharynx (Fig. 1). To complement the morphological analysis, we have sequenced the $18 \mathrm{~S}$ ribosomal DNA gene using specific primers and the obtained amplified sequences were compared with the GenBank database. Sequences were closely related to those of $D$. dievengatensis belonging to the Monhysteridae family, with $91-92 \%$ homology (Table 1). The phylogenetic analysis consistently grouped them as members of the Monhysteridae family (Fig. 2).

\section{Discussion}

In the present work, nematodes from the high-altitude Socompa Lake (3570 masl) in the Andean Puna were isolated and identified for the first time. According to the existing bibliography, only few studies gathered information about the eukaryotic microbiota in microbialites of the world. In these reports, nematodes were present in greater proportion than the rest of the eukaryotic organisms but at low diversity (Feazel et al., 2008; Allen et al., 2009; Myshrall et al., 2010; Couradeau et al., 2011).

Our results showed that the sequences were closely related to those of $D$. dievengatensis belonging to the Monhysteridae family, but the low homologies suggest the presence of new species for the genus Diplolaimella. When comparing the sequences of the SSU domain of the LSU rDNA genes between our isolated and its relatives further support that these nematodes are novel species. The molecular analysis of this study was an attempt to determine the phylogenetic position of the new isolates based on available sequences, but was not intended to be a phylogenetic study of these nematode members of the Monhysteridae family. Further DNA analysis, as well as deeper morphology studies of these nematodes would support or confirm the putative positioning inside the Monhysteridae clade.

Nematodes belonging to the Monhysteridae family, are aquatic organisms, which together with Araeolaimidae, and Chromadoridae, rep- 


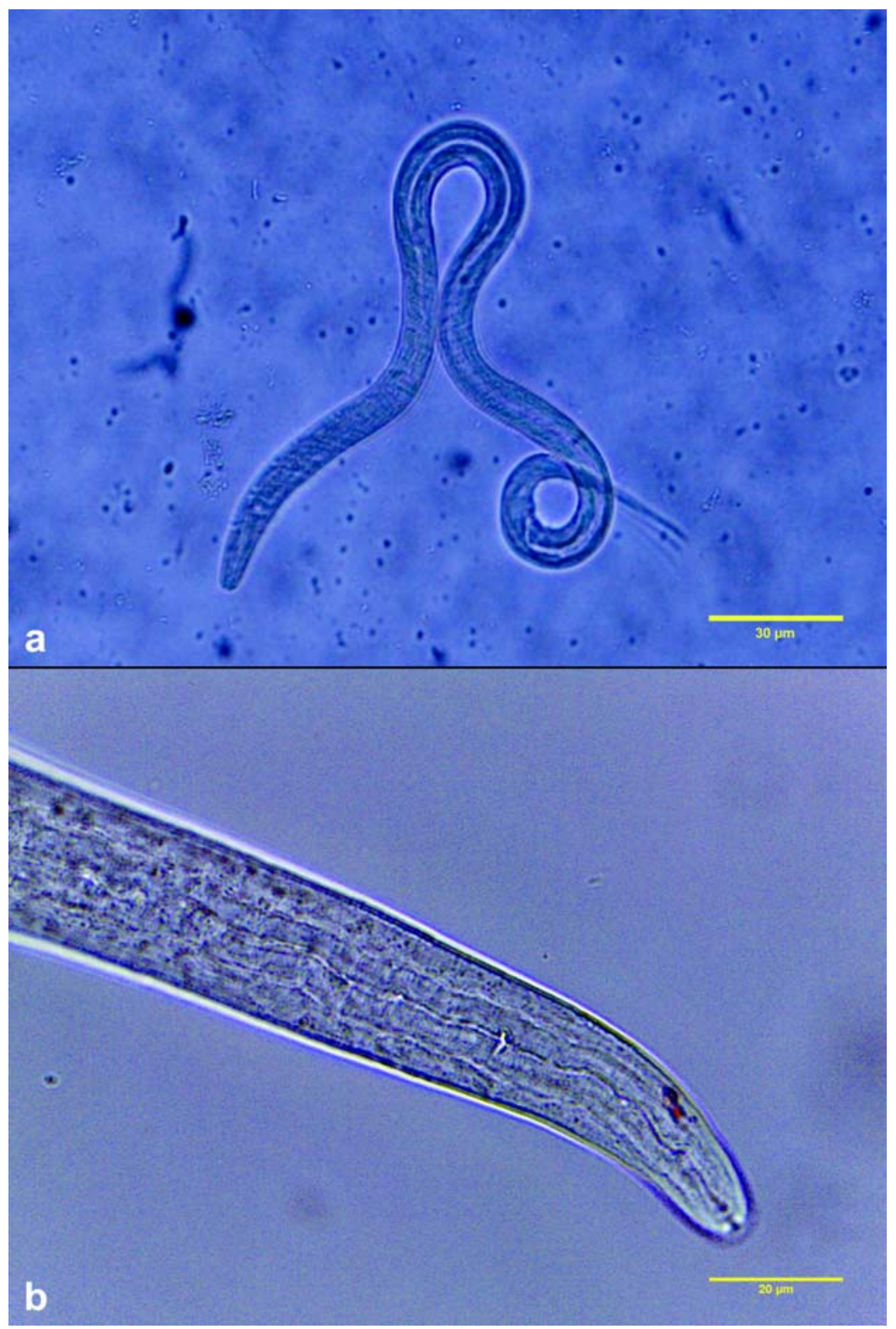

Fig. 1. Light micrographs of nematode isolated from Socompa stromatolites.

A - whole individual, $1 \mathrm{~mm}$ length; B - anterior region of the isolate showing buccal cavity and ocellus.

Рис. 1. Фотографии живых нематод, обнаруженных в строматолита озера Сокомпа.

А — целое животное с длиной тела около 1 мм; В - передний конец тела: видны ротовая полость и глазок.

resent the most frequent found families in aquatic environments with low and high salinity (De Ley et al., 2005). For example, Diplolaimelloides sp. from the Monhysteridae family are the dominant eukaryote community in the hy- persaline mats of Guerrero Negro, Mexico and Shark Bay, Australia (Feazel et al., 2008; Allen et al., 2009).

Nematodes are complex forms that have many metabolic and developmental processes 
Table 1. Identified nematodes Diplolaimella in stromatolites from Socompa Lake, Argentina. Таблица 1. Перечень видов рода Diplolaimella с указанием номеров сиквенсов из Генбанка.

\begin{tabular}{|l|c|c|c|}
\hline $\begin{array}{l}\text { Sample } \\
\text { ID }\end{array}$ & $\begin{array}{c}\text { RELATED SPECIES } \\
\text { (Blast match in GenBank) }\end{array}$ & $\begin{array}{c}\text { GenBank } \\
\text { ACCESION } \\
\text { NUMBERS }\end{array}$ & $\begin{array}{c}\text { Similarity } \\
\text { (\%) }\end{array}$ \\
\hline 1 & Diplolaimella dievengatensis (AJ966482.1) & MK121953 & 92 \\
\hline 2 & Diplolaimella dievengatensis (AJ966482.1) & MK121954 & 91 \\
\hline 3 & Diplolaimella dievengatensis (AJ966482.1) & MK121955 & 92 \\
\hline 4 & Diplolaimella dievengatensis (AJ966482.1) & MK121956 & 92 \\
\hline 5 & Diplolaimella dievengatensis (AJ966482.1) & MK121957 & 92 \\
\hline 6 & Diplolaimella dievengatensis (AJ966482.1) & MK121958 & 92 \\
\hline 7 & Diplolaimella dievengatensis (AJ966482.1) & MK121959 & 92 \\
\hline 9 & Diplolaimella dievengatensis (AJ966482.1) & MK121960 & 92 \\
\hline 10 & Diplolaimella dievengatensis (AJ966482.1) & MK121961 & 91 \\
\hline 12 & Diplolaimella dievengatensis (AJ966482.1) & MK121962 & 92 \\
\hline 13 & Diplolaimella dievengatensis (AJ966482.1) & MK121963 & 92 \\
\hline
\end{tabular}

comparable to higher taxa. An interesting aspect of these invertebrates is their remarkable ability to withstand stress and adverse conditions, due to certain features they own, such as morphological plasticity, physiological adaptability and ecological diversity (Tahseen, 2012). Monhysteridae nematodes are commonly found in marine sediments and are prevalent at the oxic-anoxic boundary (Steyaert et al., 1999). These nematodes are recognized for accelerating the decomposition processes in hypersaline sediments. The mechanisms by which they carry out this process are not yet known but many eukaryotes are known to bioturbate sediments and graze (Farmer, 1992). Such mechanisms stimulate bacterial community activity and have been proposed as an explanation for the development and coexistence of clotted mat structures such as thrombolites in the same vicinity as laminated mat structures (Reichardt, 1988).

Based on the information collected and the data obtained, we can conclude that in the Andean Socompa Lake there are eukaryotic organisms belonging to the Phylum Nematoda, from Monhysteridae family and related with Diplolaimellasp. genus. These nematodes might have special adaptive characteristics to survive in the extreme environments from the Andean Puna, hence represent good subjects for study- ing the ways in which eukaryotes adapt to environmental stresses.

Currently, further studies are being carried out with samples from Socompa Lake to identify and report all the nematode community by metagenomic approaches.

\section{Funding}

This study was partially funded by Proyectos de Investigación Científica y Tecnológica (PICT) 730 and 3825.

\section{Compliance with ethical standards}

Conflict of Interest: The authors declare that they have no conflict of interest.

Ethical approval: This article does not contain any studies with animals performed by any of the authors.

Sampling and field studies: All necessary permits for sampling and observational field studies have been obtained by the authors from the competent authorities and are mentioned in the acknowledgements, if applicable.

\section{Data availability}

The datasets generated during and/or analyzed during the current study are available in the NCBI repository, https://www.ncbi.nlm. nih.gov/ 


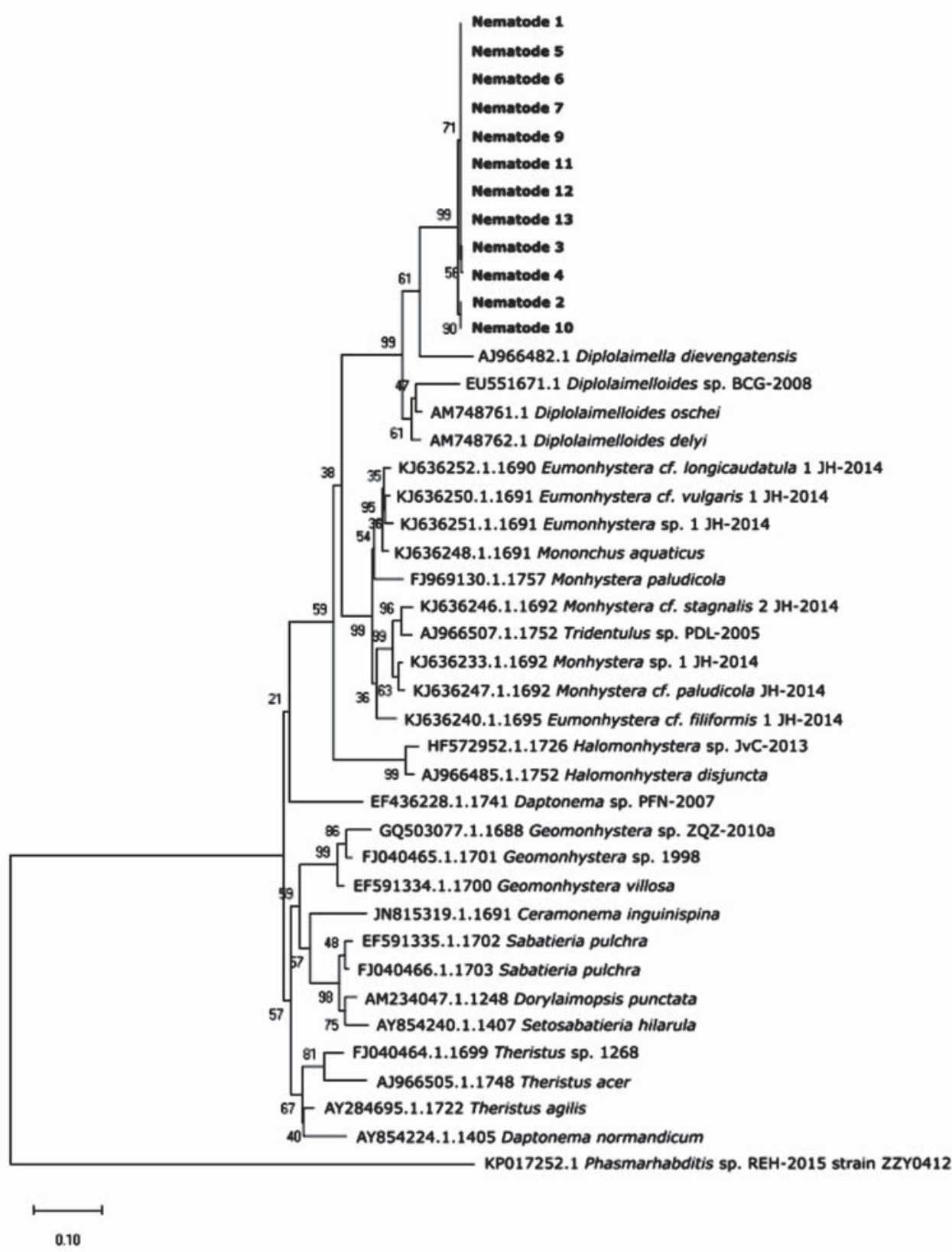

Fig. 2. Maximum-likelihood tree inferred from SSU rDNA sequences. GenBank and strain ID associated with DNA sequences are shown on the left and right of the species name respectively. The nematodes newly sequenced in this study are highlighted in bold. The numbers at each node represent bootstrap support. The scale bar represents inferred evolutionary distance in substitutions/site

Рис. 2. Филогенетическое дерево, построенное методом максимального правдоподобия на основе данных сиквенсов генов $18 \mathrm{~S}$. 


\section{Supporting Information}

Additional Supporting Information may be found online in the supporting tab for this article.

Video S1. Nematodes with high mobility obtained by the agar extraction method, from stromatolites of the Andean Puna.

Видеофильм S1. Видеосъемка живых активно движущихся нематод, извлеченных на агаровую среду из строматолитов Андского плоскогорья.

\section{References}

Allen M.A., Goh F., Burns B.P., Neilan B.A. 2009. Bacterial, archaeal and eukaryotic diversity of smooth and pustular microbial mat communities in the hypersaline lagoon of Shark Bay // Geobiol. Vol.7. P.82-96. doi: $10.1111 / \mathrm{j} .1472-4669.2008 .00187 . x$

Barker K.R. 1998. Introduction and synopsis of advancements in nematology // K.R. Barker, G.A. Pederson, G.L. Windham (eds.). Plant and Nematode Interactions. Madison, WI, USA. American Society of Agronomy, Crop Science Society of America, and Soil Science Society of America. 20 p.

Barrière A., Félix M.A. 2006. Isolation of C. elegans and related nematodes // WormBook (ed.). The C. elegans Research Community. WormBook; doi/10.1895/ wormbook.1.115.1, http://www.wormbook.org.

Blaxter M.L., De Ley P., Garey J., Liu L.X. 1998. A molecular evolutionary framework for the phylum Nematoda// Nature. Vol.392. P.71-75. https://doi.org/ $10.1038 / 32160$

Brenner S. 1974. The genetics of Caenorhabditis elegans // Genetics. Vol.77. No.1. P.71-94.

Couradeau E., Benzerara K., Moreira D., Gérard E. 2011. Prokaryotic and Eukaryotic Community Structure in Field and Cultured Microbialites from the Alkaline Lake Alchichica (Mexico) // PLoS ONE. Vol.6. No.12. P.28767. https://doi.org/10.1371/journal.pone. 0028767.

De Ley P., De Ley I.T., Morris K., Abebe E. 2005. An integrated approach to fast and informative morphological vouchering of nematodes for applications in molecular barcoding // Philos. Trans. R. Soc. Lond. B. Biol. Sci. Vol.360. No.1462. P.1945-1958. doi: 10. 1098/rstb.2005.1726.

Farías M.E., Rascovan N., Toneatti D.M., Albarracín V.H. 2013. The Discovery of Stromatolites Developing at $3570 \mathrm{~m}$ above Sea Level in a High-Altitude Volcanic Lake Socompa, argentinean Andes // PLoS ONE. Vol.8. No.1. P.53497. doi: 10.1371/journal.pone. 0053497.

Farmer J.D. 1992. Grazing and bioturbation in modern microbial mats // J.W. Schopf, C. Klein (eds.). The Proterozoic Biosphere: A Multidisciplinary Study. Cambridge, U.K. Cambridge University Press. P.295298.

Feazel L.M., Spear J.R., Berger A.B., Harris J.K., Frank D.N., Ley R.E., Pace N.R. 2007. Eucaryotic diversity in a hypersaline microbial mat // App. Environ. Mi- crobiol. Vol.74. No.1. P.329-332. doi:10.1128/AEM. 01448-07.

Gorriti M.F., Dias G.M., Chimetto L.A., Trindade-Silva A.E., Silva B.S., Mesquita M.M., Thompson F.L. 2014. Genomic and phenotypic attributes of novel salinivibrios from stromatolites, sediment and water from a high altitude lake // BMC Gen. Vol.15. P.473. doi: 10.1186/1471-2164-15-473.

Haber M., Schungel M., Putz A., Muller S., Hasert B., Schulenburg H. 2005. Evolutionary history of Caenorhabditis elegans inferred from microsatellites: evidence for spatial and temporal genetic differentiation and the occurrence of outbreeding // Mol. Biol. Evol. Vol.22. P.160-173. doi: 10.1093/molbev/msh264.

Houston J., Hartley A.J. 2003. The central Andean westslope rainshadow and its potential contribution to the origin of hyper-aridity in the Atacama Desert // Intern. J. Climatol. Vol.23. P.1453-1464. https://doi.org/ 10.1002/joc. 938 .

Jacobs L.J., Van De Velde M.C., Geraert E., Vranken G. 1990. Description of Diplolaimela dievengatensis sp. $\mathrm{n}$. (Nematoda: Monhysteridae)// Nematol. Vol.36. P.1-21.

Kumar S., Stecher G., Li M., Knyaz C., Tamura K. 2018. MEGA X: Molecular evolutionary genetics analysis across computing platforms // Mol. Biol. Evol. Vol.35. P.1547-1549. doi: 10.1093/molbev/msy096.

Luccini E., Cede A., Piacentini R., Villanueva C. 2006. Ultraviolet climatology over Argentina // J. Geophys. Res. Atmos. Vol.111. No.D17.https://doi.org/10.1029/ 2005JD006580.

Maldonado J. 2014. [Archeas biodiversity en Andes extreme environments. Stress resistant systems. Tesis de Posgrado, Facultad de Ciencias Naturales e I.M.L, Universidad Nacional de Tucumán, San Miguel de Tucumán, Argentina] [In Spanish].

Myshrall K.L., Mobberley J.M., Green S.J., Visscher P.T. 2010. Biogeochemical cycling and microbial diversity in the thrombolytic microbialites of Highborne Cay, Bahamas // Geobiol. Vol.8. P.337-354. doi: 10. 1111/j.1472-4669.2010.00245.x.

Pruesse E., Peplies J., Glöckner F.O. 2012. SINA: accurate high-throughput multiple sequence alignment of ribosomal RNA genes // Bioinform. Vol.28. P.18231829. doi: 10.1093/bioinformatics/bts252.

Reichardt W. 1988. Impact of bioturbation by Arenicola marina on microbiological parameters in intertidal sediments // Mar. Ecol. Prog. Ser. Vol.44. P.149-158. doi: $10.3354 /$ meps044149.

Steyaert M., Garner N., Van Gansbeke D., Vincx M. 1999. Nematode communities from the North Sea: Environmental controls on species diversity and vertical distribution within the sediment // J. Mar. Biol. Assoc. U.K. Vol.79. No.2. P.253-264.

Tahseen Q. 2012. Nematodes in aquatic environments: adaptations and survival strategies // Biodiver. J. Vol.3. No.1. P.13-40.

Walter M.R. 1976. Introduction // M.R. Walter (ed.). Stromatolites. Amsterdam. Elsevier. P.1-3. https:// doi.org/10.1016/S0070-4571(08)71123-3.

Zappettini E.O., Blasco G. 2001. [Geologic Paper 2569-II, Socompa, Salta, República Argentina // Servicio Geológico Minero Argentino Buletín 26, 65]. [In Spanish]

Responsible editor E.N. Temereva 